\title{
Enhancement of Fixation Nitrogen in Food Legumes
}

\author{
Edi Wiraguna (Corresponding author) \\ Associate Bachelor of Bogor Agricultural University \\ Jl. Kumbang No. 14, Bogor, 16151, Indonesia
}

Received: February 1, 2016 Accepted: February 16, 2016 Published: February 21, 2016

doi:10.5296/jas.v4i2.9065 URL: http://dx.doi.org/10.5296/jas.v4i2.9065

\begin{abstract}
Increasing the capability of nitrogen fixation in legumes is crucial because the population has been risen dramatically and predicted to be doubled by 2050. In order to feed this high population, food productivity needs to be increased. A solution to overcome this problem is through improvement of crop productivity by applying fertilizer. However, the application of fertilizer such as nitrogen is over the recommended amount and the cost is high at approximately \$US 40 billion per year. Therefore, legumes are important in order to minimize the cost and enhance soil fertility through nitrogen fixation (nodulation). To achieve high nitrogen fixation, agriculture managements such as minimum tillage, breeding programs and induced mutants have been developed. In breeding program, it was found that BT-477 had high nitrogen fixation and drought tolerant based on selection among 7 common bean genotypes. Induced mutants were applied by soaking swollen seeds in EMS and resulted to higher number of nodules (10x).
\end{abstract}

Keywords: Legumes, nitrogen, nodulation, agriculture

\section{Introduction}

Success of green revolution in the middle of 20 century took a large part of applying fertilizer to increase plant productivity. This is because most crops which had been cultivated were responsive to high level of fertilizer particularly nitrogen. Therefore, large amount of nitrogen fertilizer has been applied. For example, approximately 100 billion $\mathrm{kg}$ Nitrogen, equal to \$US 40 billion, was needed in worldwide cereal and oilseeds crop productions annually (Herridge and Rose, 2000).

In addition, in less than 10 decades, population has increased from almost 6 million to more than 7 million people and food price index has dramatically risen from 1.3 to 1.5 in last 5 years (FAO, 2014). It is also predicted that between 2001 and 2050, global food production will need to be doubled (Emerich and Krishnan, 2009). Moreover, the latter authors added that to meet with this productivity the application of nitrogen fertilizer needs to be increased 
for almost three times. Thus, research on legume is vital to improve the amount of nitrogen in soil by planting legumes. For instance, in lupin, $16 \%$ of nitrogen fixed is left in the soil and the rests are transferred to shoot and pod (Peoples et al., 2009).

However, most commercial legumes cannot supply nitrogen to the environment due to lack number of nodules. For example, non-nodulated soy beans do not supply nitrogen to soil but absorb as much as $158 \mathrm{~kg}$ nitrogen per ha to shoot (Peoples et al., 2009). As a consequence, the reasonable number of nodules is crucial to increase nitrogen fixation and this can be achieved through agricultural managements, breeding program or genetic mutation. For instance, in agriculture managements, lentils, soy beans and peas have higher nitrogen fixation in non-tillage than tillage (Van Kessel and Hartley, 2000).

In this review, the process of nitrogen fixation; agricultural practices and diseases which impact nitrogen fixation on food legume fixation will be explained. Finally, breeding programs involving conventional and mutation will be presented in order to enhance nitrogen fixation. The objective of this literature review is to identify the possibility of enhancing nitrogen fixation on food legumes to minimise nitrogen fertiliser.

\section{Nitrogen Fixation}

In global and regional scale, nitrogen fixation on legume is essential in order to improve $\mathrm{N}$ available in soil. In the USA, it is estimated that approximately 40 million $\mathrm{kg}$ nitrogen in soil was fixed by the presence of legumes including lentil (Lens culinaris Medik.), chick pea (Cicer arietinum L.) and field pea (Pisum sativum L.) whereas in Canada, food legumes such as dry bean (Phaseolus vulgaris L.), field pea, lentil, and chickpea could provide 171 million $\mathrm{kg}$ of nitrogen in soil (Lupwayi and Kennedy, 2007). This amount provided approximately $7 \%$ fixed nitrogen in the soil which could be used for next crop in rotation system. In global scale, legumes are approximately cultivated in 250 million hectares and they can provide about 90 trillion $\mathrm{kg} \mathrm{N}$ per year (Graham and Vance, 2000). Moreover, this availability of legumes to provide nitrogen in the soil is through nodulation formation by nitrogenase enzyme.

Nitrogenase is an important enzyme because it catalyzes dinitrogen to ammonia (Dixon and Kahn, 2004). These enzymes are complex mettalo enzymes consisted of mechanism process with structural characters (Rees and Howard, 2000). Moreover, nitrogenase is categorized into two, which are iron (Fe) protein and molybdenum-iron (MoFe) (Dixon and Kahn, 2004).

All bacteria and archarea which are able to transform nitrogen gas into useful form such as ammonia are called diazotrophs. The diazotrophs such as Azotobacter vinelandii and Rhodobacter capsulatus perform molybdenum to transform nitrogen gas (Eady, 1996). In this process, oxygen is a crucial component because it is used as a bridge of two subunit dimer [4Fe-4S] clusters. In Azotobacter vinelandii, dimer cluster is found in Fe protein and MoFe protein consisting of FeMo cofactor and $\mathrm{P}$ cluster which are essential on reduction nitrogen (Einsle et al., 2002). If reduction on optimum condition, this can produce 2 moles of ammonia $\left(\mathrm{NH}_{3}\right)$ with the formulation as follows:

$$
\mathrm{N}_{2}+8 \mathrm{e}-+8 \mathrm{H}++16 \mathrm{Mg} \mathrm{ATP} \rightarrow 2 \mathrm{NH}_{3}+\mathrm{H}_{2}+16 \mathrm{Mg} \mathrm{ADP}+16 \mathrm{Pi} \text { (equation 1) }
$$


Each step of catalytic cycle of nitrogenase is an extensive energetic input because it needs 16 MgATP to produce a pair of ammonium (equation 1). In addition, a slow time of ammonium production influences nitrogen bacteria to synthesize large amount of nitrogen from environment and nitrogenase accounted for almost $20 \%$ of total protein in the cell (Dixon and Kahn, 2004).

Although most nitrogen bacteria (diazotrophs) cannot adopt in low available oxygen, some bacteria are tolerant of low available of oxygen in synthesizing nitrogen. For instance, Streptomyces thermoautotrophicus can adapt to low oxygen if it is situated on high temperature (Ribbe et al., 1997). Moreover, symbiosis of bacteria and legume roots is another way of diazotrophs to survive under limit oxygen (Dixon and Kahn, 2004). In this symbiosis, nodule cortex is performed as a barrier between the diazotrops and environment; therefore, these bacteria can have sufficient oxygen from legumes (host) (Arcondéguy et al., 1997). In addition, other diazotrophs can adapt to low oxygen by anaerobic growth to minimize oxygen consumption on respiration. Furthermore, some others can modify their genetic level. For example, Rhodobacter capsulatus can modify DraT (dinitrogenase reductase ADP-ribosyltransferase) and DraG (dinitrogenase reductase activating glycohydrolase) in response to nitrogenase and ammonium so they are able to run this process in low oxygen level (Masepohl et al., 2002).

In most legumes, nitrogen fixation is influenced by molybdenum and Fe nitrogenase. According to Masepohl et al. (2002), these enzymes are controlled by environment through three levels. First, the forming of nifA1, nifA2 and anfA is controlled by Ntr system depended on the amount of ammonium and mutations of glnB. Second, activity of NifA1, NifA2, and AnfA is influenced by the presence of ammonium, GlnK and GlnB. The final products on this level are nif and anf genes which are used in next level. Lastly, the final products of third level, which are Mo nitrogenase and Fe Nitrogenase, are influenced by GlnB, GlnK, AmtB, DraT and DraG.

\subsection{Nodulation}

Nodulation occurs through bacteria which attach on root hair curls and epidermis (Oldroyd and Downie, 2008). In root hair system, bacteria attach on root hair and the root hair deformation (curl) captures the bacteria (Figure 1). This deformation allows invasion of bacteria from epidermis to cortex. In epidermis, bacteria express a particular gene in order to be able to enter root hair through association between nodulation (Nod) and epidermis. Following this, the bacteria are imbibed to cortex through kinetic process with associated in hormone (cytokinin and auxin). In crack invasion, the bacteria are able to go through cortex because the boundary on epidermis is disturbed (Figure 1). However, the effectiveness of nodulation in both types is influenced by biological control of plant disease, incompatible some bacteria to plant immune systems and organic matter (Hardarson and Atkins, 2003; Triplett and Sadowsky, 1992). Hence, it is crucial to identify the compatible of plant immune system with the competitiveness of bacteria in order to enhance nodulation. 
Root hair invasion

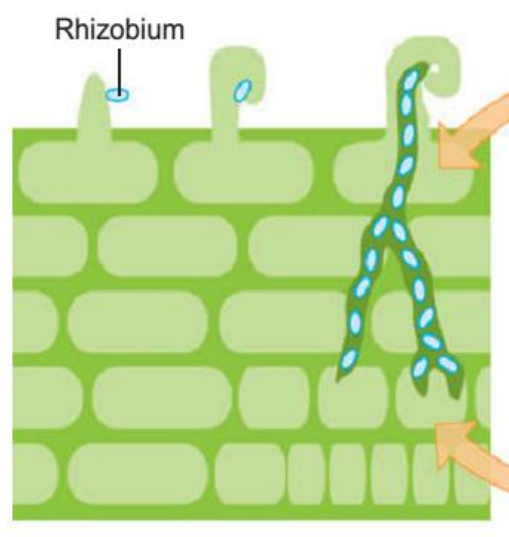

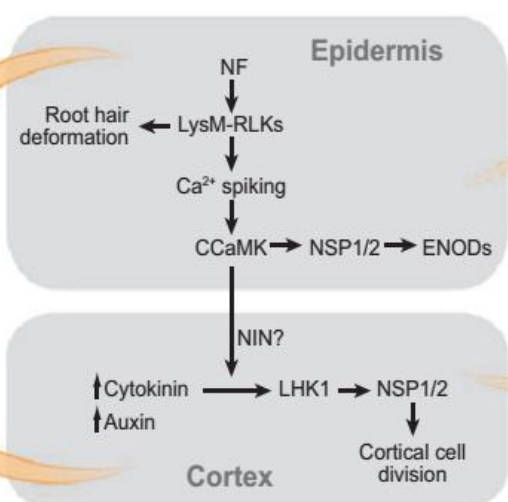

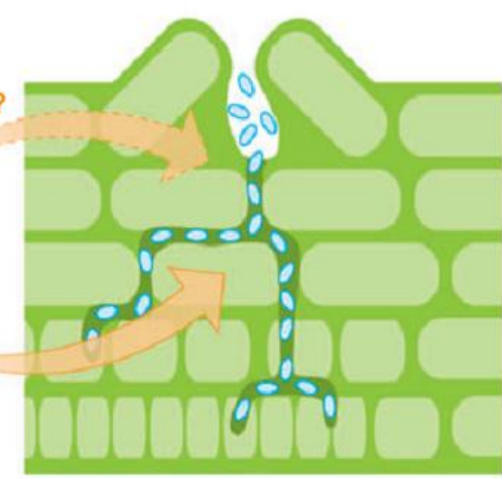

Figure 1. Two different types of nodulation by bacteria invasion (Oldroyd and Downie, 2008)

\section{Agricultural Practices}

There are some agricultural practices that need to take into account because this can influence the effectiveness of nitrogen fixation. Moreover, land crop history is also important because if legumes were planted as previous crops, inoculants would be available to enhance legume inoculation (Deaker et al., 2004). Additionally, intercropping and tillage could increase the efficiency of nitrogen fixation (Van Kessel and Hartley, 2000). Hence, nitrogen fixation on legume is influenced by inoculants, tillage and intercropping.

In inoculation, applying inoculants on legume crops increased grain yield up to $25 \%$ (Deaker et al., 2004). In pea, for example, inoculants increased shoot dry weight by $19 \%$ and nodules by 22\% (Quinn, 2009). Moreover, according to Van Kessel and Hartley (2000), inoculants might give higher results if legumes were planted in new areas, high amount of nitrogen in soil, and good environment such as appropriate soil $\mathrm{pH}$, salinity, temperature and moisture.

Table 1. Nitrogen fixation between conventional and zero/minimum tillage on legume (Van Kessel and Hartley, 2000)

\begin{tabular}{|l|c|c|}
\hline \multirow{2}{*}{ Legumes } & \multicolumn{2}{|c|}{ Fixed nitrogen (\%) } \\
\cline { 2 - 3 } & Conventional & Zero Tillage/Minimum Tillage \\
\hline Soy bean & 73 & 88 \\
\hline Pea & 48 & 79 \\
\hline Lentil & 62 & 72 \\
\hline
\end{tabular}

Cultivation such as tillage can affect nitrogen fixation on legumes. If minimum tillage or no tillage was applied, soil health would increase due to the improvement of soil organic matter, water holding capacity and soil fertility (Quinn, 2009). Moreover, in no tillage, the N available in soil rose as an implication of the improvement of nitrogen fixation on legumes. Additionally, Van Kessel and Hartley (2000) found that nodulation on soy bean (Glycine max) increased and the amount of fixed nitrogen improved from 73 to almost $90 \mathrm{Kg}$ Nitrogen per ha on minimum tillage (Table 1). 
Intercropping is another technique to improve nitrogen fixation on legumes. For example, intercropping between chickpea and wheat enhanced nitrogen content in chickpea and wheat for $10.2 \%$ and $11 \%$ respectively compare to monoculture (Gunes et al., 2007). Moreover, in peas, nitrogen fixation was greater $39 \%$ under intercropping with barley than monoculture (Beck et al., 1991). Later authors also found that nitrogen fixation can be greater in fertile soil because of the different demand of nitrogen between legume and non-legume crops.

\section{Factors Influencing Nitrogen Fixation}

In symbiosis between diazotrophs and host plants, carbohydrate from the host is used as energy sources in the nodule. Therefore, the presence of pests, pesticides and virus, which disturbs photosynthesis, can impact on the symbiosis and this can influence the effectiveness of nitrogen fixation nodule. Moreover, some insect larvae such as Sotina sp. attacked nodulation directly so it can cause severe damage to the symbiosis.

Sotina sp. (weevil) is one of main pests which attack shoot and root of legume in its life cycle. The adult damages legume leaves by feeding edge leaves and making rounded cuts on it (Bigger, 1930). Moreover, the author indentified that the larvae fed nodule and then smaller roots before attacking main root system. In addition, eggs and larvae might grow in the soil during autumn and winter and damage root system at the same time. The impact of this weevil on nodules influenced the effectiveness of nitrogen fixation by decreasing $42 \%$ of nitrogen content (Murray et al., 1996). In lupin, the pest attacked roots and nodules in larva stage and fed leaves in adult stage which caused decreasing number of pods (Ströcker et al., 2013). Furthermore, if density of weevil adults (Sitona lineatus L) was $20 \%$, it would reduce $18 \%$ seeds per pot in peas (Lohaus and Vidal, 2010).

Pesticides could also have negative impacts on symbiosis between legumes and nitrogen fixation fungus such as Arbuscular mycorrhizal (Catford et al., 2003). This is because cellulolytic and petolytic enzymes, which are useful in this symbiosis, were inhibited by the pesticide (Mahmoud and Omar, 1995). Moreover, pesticides impacted on rhizosphere due to the inhibition of the growth of plants and promoting organisms by pesticide application (Koch et al., 1997). In addition, experiments showed that pesticide decreased nodule biomass on soy bean in different soil types (Eberbach and Douglas, 1989; Mallik and Tesfai, 1985). Also, colonisation between legumes and Arbuscular mycorrhizal was inhibited due to negative impacts pesticides on spore germination (Smith and Gianinazzi-Pearson, 1988).

Virus on legumes also causes a negative impact on nodulation. Soy bean mosaic virus (SMV), for example, reduced number, size and weight of nodules and it might give severe impact when the virus infected on early stage of growing (Tu et al., 1970). Later authors added that more than $80 \%$ of yield might reduce if the infection occurred in the first two weeks of sowing. Moreover, the impact could be worse when more than one virus on a crop. In alfafa (Medicago polymorpha L.), alfafa mosaic virus could decrease nodule dry weight by almost $25 \%$ at virus infection on 53 days after planting even though there was not significantly different on the number of nodules (Wroth et al., 1993). The authors added that the reduction of dry weight caused lower nitrogen content for $24 \%$ on alfafa shoot. Furthermore, this might influence on dwarf legume plants and yellowing leaves because of nitrogen deficiency caused 
by low supply of nitrogen from nodules (Wroth et al., 1993).

\section{Breeding Program}

There are two main breeding programs which are common on enhancing nitrogen fixation on legumes. Conventional breeding program selecting and crossing the natural variation; and mutagens which is induced into legumes.

\subsection{Conventinal Breeding}

Conventional breeding is one of methods to increase nitrogen fixation in legumes through screening. In soy bean, for instance, 489 genotypes were selected for nitrogen fixation by measuring ureide content in xylem and extract of the plant (Betts and Herridge, 1987). The latter authors added that the screening method was applied by adding nitrogen fertiliser in the soil and the tolerant cultivars, 23 Korean genotypes, preferred perform nodules to adsorb nitrogen from environment than fertiliser. Conventional breeding usually is not only concerned about nitrogen fixation but also the capability to tolerant on abiotic stress such as drought. Moreover, in 2025, almost 50\% worldwide areas were projected to have water limitation (Emerich and Krishnan, 2009). Therefore, legume cultivars that can perform nitrogen fixation in drought areas or other abiotic stresses are needed.

\subsubsection{Soy Beans (Glycine max)}

Drought is one of limitation to apply nitrogen fixation and cause a $70 \%$ decrease of nitrogenase activity in 4 days of drought in soy beans (Durand et al., 1987). Experiment on nitrogen fixation in response to drought tolerant was applied by comparing 8 Jackson genotypes (Sall and Sinclair, 1991). The latter authors found that in 8 days of drought on pot experiment, nitrogen fixation was stable in all genotypes. This indicated that the genotypes were drought tolerant. However, Jackson had low yield and late of maturity; therefore, crossing Jackson with KS4895, which is high yielding genotypes (Schapaugh and Dille, 1998), had been tried to improve nitrogen fixation on high yielding genotypes. After selfing to F3, two recommended lines were established, R01-416F and R01-581F, to be resistance under moderate water deficiency (Sinclair et al., 2007).

\subsubsection{Common beans (Phaseolus vulgaris $\mathrm{L}$ )}

In glasshouse experiment, nitrogen fixation had been studied between cultivars 'Roma' and 'Kentucky Wonder' for 13 days of drought (Serraj and Sinclair, 1998). The authors concluded that Roma cultivar was more tolerant to drought than its counterpart because Roma had greater shoot and nodule biomass. As a consequence, this cultivar could be a parent for breeding program in order to increase the viability under stress condition.

In field experiment, screening seven common bean genotypes was conducted in Mexico in 1991 (Castellanos et al., 1996). The authors applied drought to three plant growth stages (drought during vegetative, generative and whole growing cycle) and control. Average nitrogen fixation in all genotypes showed that drought during generative stage impacts on the highest decrease of nitrogen fixation at $80 \%$. However, drought during vegetative stage impacts an increase by $14 \%$ of nitrogen fixation than control. This might be because delay of flowering time influences to an increase of plant capability on nitrogen fixation (Castellanos 
et al., 1996). In addition, when crops were in drought condition under generative development, the amount of nitrogen fixation was the highest at 'BAT- 477 ' by $22.6 \%$ and the lowest at X-125 by $0 \%$. Therefore, BAT-447 was recommended as parent to drought tolerant in breeding program. Moreover, in well irrigated condition, BAT-477 and Bayocel genotypes had higher nitrogen fixation and grain yield compare to others (Hardarson et al., 1993) so both genotypes were suggested as recommended genotypes to be cultivated.

\section{2 Induced Mutation}

Inducing mutant to legumes can be applied by soaking swollen seed or damaged seed coats in ethylmethane sulphonate (EMS) between 2 and 4 hours for peas (Pisum sativum) (Feenstra and Jacobsen, 1980). The latter authors concluded that although the mutation was recessive and monogenic, activity of enzyme nitrate reductase and accumulation of nitrate in peas particularly variety 'Rondo' increased. This indicated that EMS application could enhance nitrogen fixation in peas

In soy bean, EMS also was used to induce mutant plants which were able to perform nearly 10-fold nodules and increase nitrogen fixation particularly Bragg cultivar, compare to non-mutant (parents) (Carroll et al., 1985). However, after growing for 64 days in glasshouse, mutant plants, nts382, were smaller and had less biomass. This might be because the nodulation formation was recessive. Therefore, when non nodulation gene, nod49, was expressed as the plant growing, the nodulation was suppressed and impacted on smaller plants (Delves et al., 1986).

Table 2. Performance of soy bean mutants compare to commercial cultivars

\begin{tabular}{|l|l|l|}
\hline Soy bean mutants & Performances & Source \\
\hline nts 382 & smaller plant size and less biomass & Delves et al., 1986 \\
\hline nts 166 & $10 \%$ less on yield & Song et al., 1995 \\
\hline Sakukei No. 4 & smaller plant size & Ohyama, 2009 \\
\hline
\end{tabular}

However, applying induce mutation to increase nitrogen fixation through nodules was not always followed by higher productivity. For instance, study had been conducted in field experiment in the USA and Australia involving Bragg and William soy bean cultivars and their mutants showed that the mutants had less yields although higher numbers of nodules and protein (Herridge and Rose, 2000; Pracht et al., 1994). Moreover, Herridge and Rose (2000) suggested that in mutant cultivars, energy requirement to raise a capability of nitrogen fixation could not compensate for plant biomass because plants were able to allocate only $70 \%$ of their optimum to roots and shoots. In Queensland, Australia, mutants with super nodulation, Bragg and nts116 genotypes, had approximately $10 \%$ less yield than commercial cultivars (Song et al., 1995). Even though these mutants could not produce high yield, farmers in Australia cultivated the cultivars because nitrogen fertiliser could be reduced to the next crop in rotation system (Herridge and Rose, 2000). In Japan, Sakukei No. 4, which was bred from soy bean mutants (En6500), had higher nitrogen fixation but smaller plant size than commercial cultivars, Enrei (Table 2). Therefore, increasing plant density could increase productivity. In addition, the latter author added that higher yield could also be derived from 
mix-cropping between Sakukei No. 4 and sorghum or rotation with cereal crops.

\section{Conclusion}

The demand of food has increased as the rise of population. Moreover, it is projected that the food production needs to be doubled between 2001 and 2050. As a consequence, high fertiliser application has been applied to increase crop productivity. However, the price of fertiliser has increased which influencing on food price and low income on farmers especially in developing countries. Therefore, crops such as legumes, which have less fertiliser application, should be developed.

In order to release legume cultivars with low or non-nitrogen input, nitrogen fixation on the legumes could be risen through conventional breeding and mutation. However, some legumes and recommended mutant cultivars cannot perform high yielding in the field and under stress condition. Thus, further research on nitrogen fixation in legumes needs to be improved because this can minimize fertilizer application in order to gain high productivity.

\section{Acknowledgement}

Associate Bachelor of Bogor Agricultural University is greatly acknowledged for its part-funding during the publication process.

\section{References}

Abd-Alla, M. H., Omar, S. A., \& Karanxha, S. (2000). The impact of pesticides on arbuscular mycorrhizal and nitrogen-fixing symbioses in legumes. Applied Soil Ecology, 14, 191-200

Arcondéguy, T., Huez, I., Tillard, P., Gangneux, C., De Billy, F., Gojon, A., Truchet, G. \& Kahn, D. (1997). The Rhizobium meliloti PII protein, which controls bacterial nitrogen metabolism, affects alfalfa nodule development. Genes \& development, 11, 1194-1206

Beck, D., Wery, J., Saxena, M., \& Ayadi, A. (1991). Dinitrogen fixation and nitrogen balance in cool-season food legumes. Agronomy journal, 83, 334-341

Betts, J. \& Herridge, D. (1987). Isolation of soybean lines capable of nodulation and nitrogen fixation under high levels of nitrate supply. Crop science, 27, 1156-1161

Bigger, J. (1930). Notes on the life history of the clover root curculio, Sitona hispidula Fab., in central Illinois. Journal of Economic Entomology, 23, 334-342

Carroll, B. J., Mcneil, D. L. \& Gresshoff, P. M. (1985). Isolation and properties of soybean [Glycine $\max (\mathrm{L}$.$) Merr.] mutants that nodulate in the presence of high nitrate concentrations.$ Proceedings of the National Academy of Sciences, 82, 4162-4166

Castellanos, J., Pena-Cabriales, J. \& Acosta-Gallegos, J. (1996). 15N-determined dinitrogen fixation capacity of common bean (Phaseolus vulgaris) cultivars under water stress. The Journal of Agricultural Science, 126, 327-333

Catford, J. G., Staehelin, C., Lerat, S., Piché, Y. \& Vierheilig, H. (2003). Suppression of arbuscular mycorrhizal colonization and nodulation in split - root systems of alfalfa after pre 
- inoculation and treatment with Nod factors. Journal of Experimental Botany, 54, 1481-1487

Deaker, R., Roughley, R. J. \& Kennedy, I. R. (2004). Legume seed inoculation technology-a review. Soil Biology and Biochemistry, 36, 1275-1288

Delves, A. C., Mathews, A., Day, D. A., Carter, A. S., Carroll, B. J. \& Gresshoff, P. M. (1986). Regulation of the soybean-Rhizobium nodule symbiosis by shoot and root factors. Plant Physiology, 82, 588-590

Dixon, R. \& Kahn, D. (2004). Genetic regulation of biological nitrogen fixation. Nature Reviews Microbiology, 2, 621-631

Durand, J., Sheehy, J. \& Minchin, F. (1987). Nitrogenase activity, photosynthesis and nodule water potential in soyabean plants experiencing water deprivation. Journal of experimental botany, 38, 311-321

Eady, R. R. (1996). Structure-function relationships of alternative nitrogenases. Chemical reviews, 96, 3013-3030

Eberbach, P. \& Douglas, L. (1989). Herbicide effects on the growth and nodulation potential of Rhizobium trifolii with Trifolium subterraneum L. Plant and Soil, 119, 15-23

Einsle, O., Tezcan, F. A., Andrade, S. L., Schmid, B., Yoshida, M., Howard, J. B. \& Rees, D. C. (2002). Nitrogenase MoFe-protein at $1.16 \AA$ resolution: a central ligand in the FeMo-cofactor. Science, 297, 1696-1700

Emerich, D. W. \& Krishnan, H. B. (2009). Nitrogen fixation in crop production, ASA-CSSA-SSSA.

Feenstra, W. \& Jacobsen, E. (1980). Isolation of a nitrate reductase deficient mutant of Pisum sativum by means of selection for chlorate resistance. Theoretical and Applied Genetics, 58, $39-42$

Food and Agriculture Organisation (FAO). (2014). FOASTAT database collection Food and Agriculture Organization of The United Nations Statistics Division. [Online] Available at: http://faostat3.fao.org /faostat-gateway/go/to/browse/D/*/E (July, 2014).

Graham, P. H. \& Vance, C. P. (2000). Nitrogen fixation in perspective: an overview of research and extension needs. Field Crops Research, 65, 93-106

Gunes, A., Inal, A., Adak, M. S., Alpaslan, M., Bagci, E. G., Erol, T. \& Pilbeam, D. J. (2007). Mineral nutrition of wheat, chickpea and lentil as affected by mixed cropping and soil moisture. Nutrient Cycling in Agroecosystems, 78, 83-96

Hardarson, G. \& Atkins, C. (2003). Optimising biological N2 fixation by legumes in farming systems. Plant and Soil, 252, 41-54

Hardarson, G., Bliss, F. A., Cigales-Rivero, M., Henson, R. A., Kipe-Nolt, J. A., Longeri, L., Manrique, A., Pena-Cabriales, J., Pereira, P. A. A. \& Sanabria, C. (1993). Genotypic variation 
in biological nitrogen fixation by common bean. Enhancement of Biological Nitrogen Fixation of Common Bean in Latin America. Netherlan: Springer.

Herridge, D. \& Rose, I. (2000). Breeding for enhanced nitrogen fixation in crop legumes. Field Crops Research, 65, 229-248

Koch, M., Tanami, Z., Bodani, H., Wininger, S. \& Kapulnik, Y. (1997). Field application of vesicular-arbuscular mycorrhizal fungi improved garlic yield in disinfected soil. Mycorrhiza, 7, 47-50

Lohaus, K. \& Vidal, S. (2010). Abundance of Sitona lineatus L. (Col., Curculionidae) in peas (Pisum sativum L.): Effects on yield parameters and nitrogen balance. Crop Protection, 29, 283-289

Lupwayi, N. Z. \& Kennedy, A. C. (2007). Grain Legumes in Northern Great Plains. Agronomy journal, 99, 1700-1709

Mahmoud, A.-L. \& Omar, S. (1995). Growth, cell wall-degrading enzymes and aflatoxin production by lemon-rotting fungi in relation to insecticide application. Microbiological research, 150, 195-200

Mallik, M. \& Tesfai, K. (1985). Pesticidal effect on soybean-rhizobia symbiosis. Plant and Soil, 85, 33-41

Masepohl, B., Drepper, T., Paschen, A., Groß, S., Pawlowski, A., Raabe, K., Riedel, K.U. \& Klipp, W. (2002). Regulation of nitrogen fixation in the phototrophic purple bacterium Rhodobacter capsulatus. Journal of molecular microbiology and biotechnology, 4, 243-248

Murray, P., Hatch, D. \& Cliquet, J. (1996). Impact of insect root herbivory on the growth and nitrogen and carbon contents of white clover (Trifolium repens) seedlings. Canadian Journal of Botany, 74, 1591-1595

Ohyama, T. (2009). Nitrogen fixation and metabolism in soybean plants. Netherland: Springer.

Oldroyd, G. E. \& Downie, J. A. (2008). Coordinating nodule morphogenesis with rhizobial infection in legumes. Annuals. Revolution Plant Biology, 59, 519-546

Peoples, M. B., Unkovich, M. J. \& Herridge, D. F. (2009). Measuring Symbiotic Nitrogen Fixation by Legumes. In: EMERICH, D. W. \& Krishnan, H. (eds.) Nitrogen Fixation in Crop Production. American Society of Agronomy, Crop Science Society of America, Soil Science Society of America.

Pracht, J., Nickell, C., Harper, J. \& Bullock, D. (1994). Agronomic evaluation of non-nodulating and hypernodulating mutants of soybean. Crop science, 34, 738-740

Quinn, M. A. (2009). The Lentil: Botany, Production and Uses. Netherland: Springer (Chapter 15)

Rees, D. C., \& Howard, J. B. (2000). Nitrogenase: standing at the crossroads. Current 
opinion in chemical biology, 4, 559-566

Ribbe, M., Gadkari, D., \& Meyer, O. (1997). $\mathrm{N}_{2}$ Fixation by Streptomyces thermoautotrophicus Involves a Molybdenum-Dinitrogenase and a Manganese-Superoxide Oxidoreductase That Couple $\mathrm{N}_{2}$ Reduction to the Oxidation of Superoxide Produced from $\mathrm{O}_{2}$ by a Molybdenum-CO Dehydrogenase. Journal of Biological Chemistry, 272, 26627-26633

Sall, K., \& Sinclair, T. (1991). Soybean genotypic differences in sensitivity of symbiotic nitrogen fixation to soil dehydration. Plant and Soil, 133, 31-37

Schapaugh, W., \& Dille, R. (1998). Registration of 'KS4895'soybean. Crop Science, 38, 892

Serraj, R., \& Sinclair, T. R. (1998). $\mathrm{N}_{2}$ Fixation Response to Drought in Common Bean (Phaseolus vulgaris L.). Annals of Botany, 82, 229-234

Sinclair, T. R., Purcell, L. C., King, C. A., Sneller, C. H., Chen, P., \& Vadez, V. (2007). Drought tolerance and yield increase of soybean resulting from improved symbiotic $\mathrm{N}_{2}$ fixation. Field Crops Research, 101, 68-71

Smith, S. \& Gianinazzi-Pearson, V. (1988). Physiological interactions between symbionts in vesicular-arbuscular mycorrhizal plants. Annual review of plant physiology and plant molecular biology, 39, 221-244

Song, L., Carroll, B., Gresshoff, P., \& Herridge, D. (1995). Field assessment of supernodulating genotypes of soybean for yield, $\mathrm{N}_{2}$ fixation and benefit to subsequent crops. Soil Biology and Biochemistry, 27, 563-569

Ströcker, K., Wendt, S., Kirchner, W. H. \& Struck, C. (2013). Feeding preferences of the weevils Sitona gressorius and Sitona griseus on different lupin genotypes and the role of alkaloids. Arthropod-Plant Interactions, 7, 579-589

Triplett, E. W., \& Sadowsky, M. J. (1992). Genetics of competition for nodulation of legumes. Annual Reviews in Microbiology, 46, 399-422

Tu, J., Ford, R., \& Quiniones, S. (1970). Effect of soybean mosaic virus and/or bean pod mottle virus infection on soybean nodulation. Phytopathology, 60, 518-523

Van Kessel, C., \& Hartley, C. (2000). Agricultural management of grain legumes: has it led to an increase in nitrogen fixation?. Field Crops Research, 65, 165-181

Wroth, J., Dilworth, M. \& Jones, R. (1993). Impaired nodule function in Medicago polymorpha L. infected with alfalfa mosaic virus. New phytologist, 124, 243-250

\section{Copyright Disclaimer}

Copyright for this article is retained by the author(s), with first publication rights granted to the journal.

This is an open-access article distributed under the terms and conditions of the Creative Commons Attribution license (http://creativecommons.org/licenses/by/3.0/). 